\title{
近接デジタル写真測量における民生用デジタルカメラの精度評価
}

\section{Performance Evaluation of Consumer Grade Digital Cameras for Digital Close Range Photogrammetry}

\author{
高橋 洋二*・近津 博文* \\ Yoji TAKAHASHI and Hirofumi CHIKATSU
}

\begin{abstract}
Recently, pixel numbers and functions of consumer grade digital cameras are amazingly increasing by modern semiconductor and digital technology, and there are many low-priced consumer grade digital cameras which have more than 10 mega pixels on the market in Japan. For example, 14.7 Mega consumer grade digital cameras have already appeared on the market in 2008 .

In these circumstances, convenient digital photogrammetry using consumer grade digital cameras are enormously expected in various application fields. There is a large body of literature and software on the calibration of consumer grade digital cameras. However, there are still problems for efficient digital photogrammetry using consumer grade digital cameras. These problems are performance evaluation of consumer grade digital cameras from the view point of stability, reliability, robustness of housing and physical integrity of the camera, and evaluation of repeated utilization of interior orientation parameters which was obtained beforehand.

With this motive, performance evaluations of consumer grade digital cameras are investigated in this paper with respect to stability, reliability, robustness and issue for repeated utilization of interior orientation parameters using 50 consumer grade digital cameras.
\end{abstract}

\section{1.はじめに}

ここ10年程の間に民生用デジタルカメラの高解像 度・多機能化㧍よび低価格化が飛躍的な勢いで進む中, 市場には多種多様な民生用デジタルカメラが登場し, 2008年には1,400万画素を超えるCCD センサを搭載 した民生用デジタルカメラが発売されている。このよ うな背景から，民生用デジタルカメラによるデジタル 写真測量に対する期待は大きく，これまでに民生用デ ジタルカメラの実用化に関する研究が多数報告されて いる(例えば, Habib \& Morgan, 2003 ; Fraser \& Hanley，2004； Laebe \& Foerstner，2004)。筆者ら も同様な背景から長年にわたり民生用デジタルカメラ のデジタル写真測量への応用を学術的に検証してきた 結果，筆者らが現在までに検証を行なってきた民生用 デジタルカメラは50機種にも達し, これらの結果から

*東京電機大学理工学部 建設環境工学科

「写真測量とリモートセンシング」VOL. 49，NO. 4， 2010
民生用デジタルカメラをデジタル写真測量に利用する 場合には民生用デジタルカメラの焦点距離, 主点位置 やレンズ歪みなどの内部標定要素の評価が重要である ことを示してきた（例えば，近津ら，2001；近津ら, 2003 ; 高橋・近津, 2008)。

いっぽう, 民生用デジタルカメラによるデジタル写 真測量の実用化が進む中, 予好求めておいた内部標定 要素の值を繰り返し使用する光景を度々目にするが, 写真測量におけるカメラキャリブレーションとは主点 位置, 画面距離, レンズ歪みなどの内部標定要素の值

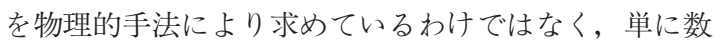
学モデルを満たす值として得られるものであることを 考慮すると, 予好求娲部標定要素の值を繰り返し 使用することの妥当性について認識しておくことの必 要性を感じる。

そこで, 本研究では筆者らが検証してきた $30 \sim 1,470$ 万画素の民生用デジタルカメラ 13 社 50 機種のすべてを 用いて，民生用デジタルカメラの内部標定要素が計測 精度に及ぼす影響について改めて検証を行ない民生用 デジタルカメラによるデジタル写真測量の実用性につ 
表 1 民生用デジタルカメラの主な諸元

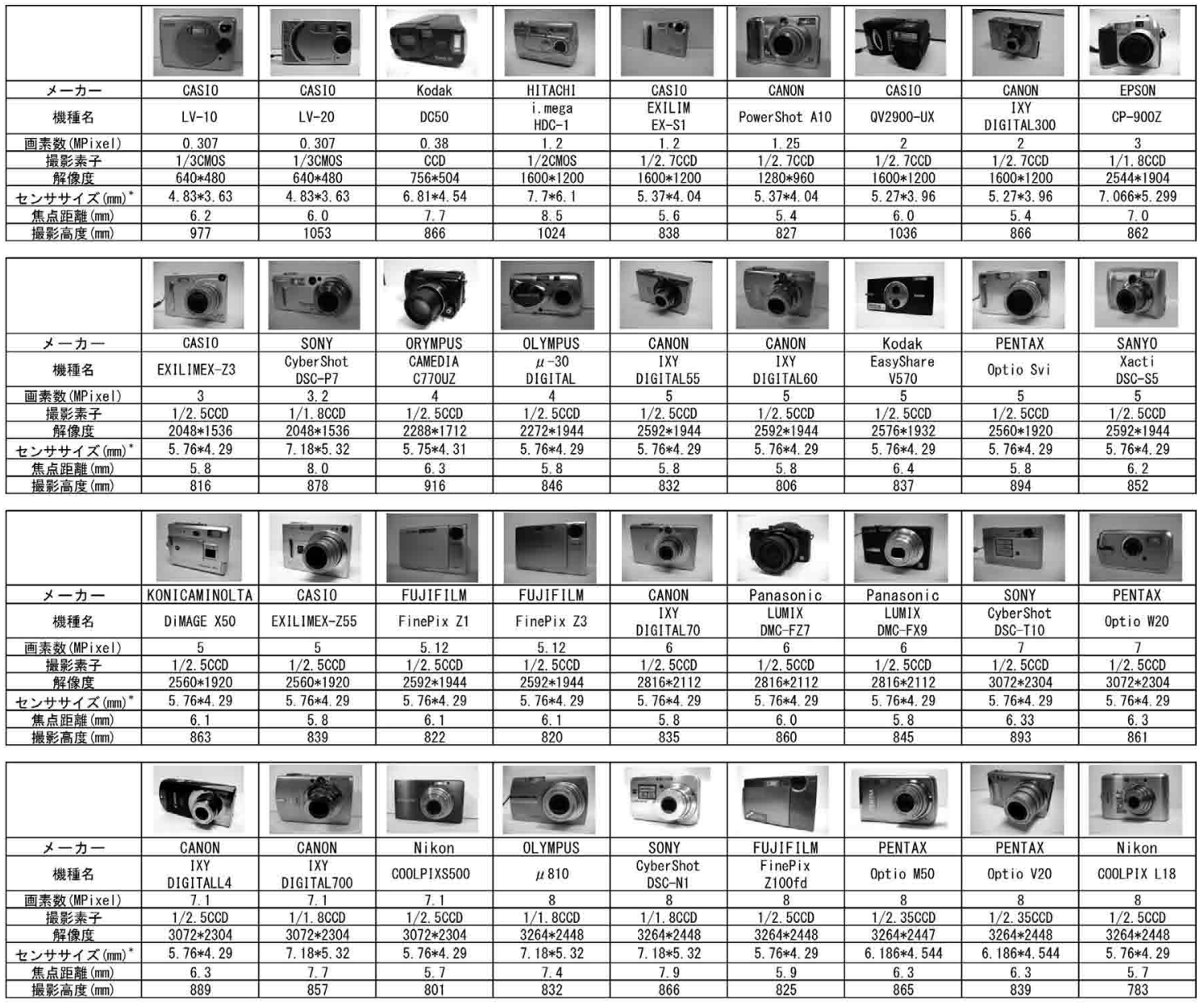

\begin{tabular}{|c|c|c|c|c|c|c|c|c|c|}
\hline & & & & - & & & & In & \\
\hline$x$-カー & FUJIFILM & ORYMPUS & CASI0 & CANON & Nikon & Kodak & PENTAX & PENTAX & Panasonic \\
\hline 機軖名 & FinePix F40fd & $\mu 830$ & $\begin{array}{l}\text { EXILIM } \\
\text { EX-Z1000 }\end{array}$ & IXYDIGITALI000 & $\begin{array}{c}\text { CoOLPIX } \\
\text { S600 }\end{array}$ & $\begin{array}{l}\text { Easyshare } \\
\text { V1003 }\end{array}$ & Optio W60 & Optio M60 & $\begin{array}{c}\text { LUIIX } \\
\text { DMC-FX100 }\end{array}$ \\
\hline 画素数 (MPixel) & 8.3 & 8.5 & 10 & 10 & 10 & 10 & 10 & 10 & 12 \\
\hline 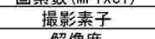 & $1 / 1.6 C C D$ & $1 / 2.35 \mathrm{CCD}$ & $1 / 1.8 \mathrm{CCD}$ & $1 / 1.8 \mathrm{CCD}$ & $1 / 2.33 \mathrm{CCD}$ & $1 / 1.8 C C D$ & $1 / 2.3 \mathrm{CCD}$ & $1 / 2.3 \mathrm{CCD}$ & $1 / 1.72 \mathrm{CCD}$ \\
\hline 解僄度 & $3296 * 2472$ & $3264 * 2448$ & $3648 * 2736$ & $3648 * 2736$ & $3648 * 2736$ & $3648 * 2736$ & $3648 * 2736$ & $3648 * 2736$ & $4000 * 3000$ \\
\hline センササイズ $(\mathrm{mm})^{*}$ & $7.69 * 5.77$ & $6.009 * 4.507$ & $7.18 * 5.32$ & $7.18 * 5.32$ & $6.18 * 4.64$ & $7.18 * 5.32$ & $6.18 * 4.64$ & $6.129 * 4.569$ & $7.4 * 5.55$ \\
\hline 焦点距離 $(\mathrm{mm})$ & 8.0 & 6.4 & 7.9 & 7.8 & 5.0 & 7.5 & 5.0 & 6.3 & 6.0 \\
\hline $\begin{array}{l}\text { 撮影高度 }(\mathrm{mm}) \\
\end{array}$ & 849 & 844 & 875 & 876 & 677 & 827 & 631 & 799 & 702 \\
\hline
\end{tabular}

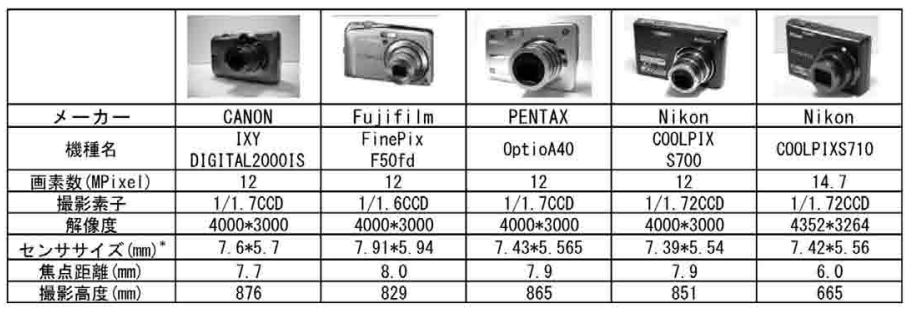




\section{2. 民生用デジタルカメラ}

民生用デジタルカメラの内部標定要素が計測精度に 及ぼす影響および内部標定要素の繰り返し使用の妥当 性を検証するにあたり本研究で使用したカメラ50機種 の主な諸元を表 1 に示す。

\section{3. 実験概要}

実験は図 1 に示すテストターゲット（H：480mm, W : 640mm, D : 20mm) を用いて，画像縮尺がほぼ一 定となるように撮影高度を調整し, 基線比 0.34 として 各カメラに対してトリプレット撮影を 5 回ずつ行なう ものであるが，各画像は撮影ごとにレンズを焦点距離 のテレ端に移動させた後, ワイド端に戻して取得され たものである。また，テストターゲットの中央 3 列は 高さ $20 \mathrm{~mm}$ であり, 各円形ターゲットの加工精度は土 $0.05 \mathrm{~mm}$ である。精度検証は図中の白丸で印した基準 点13点を用いてカメラキャリブレーションをそれぞれ 実施し, 黒枠で印した検証点 86 点に対する三次元座標 を算出して評価を行なうこととする。なおこれらの 点の画素座標は撮影した画像に二值化処理を施した 後，面積重心として算出したものである。

いっぽう, トリプレット画像のうち中央画像はレン ズ歪み（第3.3項, 図 3 ), 主点位置の変動（第4.1項, 図 5 ), キャリブレーションパラメータの変動比(第 4.3 項, 図 8 ）に対して使用するものであり, 左右のステ レオ画像は精度検証における安定性(第4.1項, 困 4 ), 信頼性（第4.2項，困 6), 堅牢性（第4.3項, 困 7 ）に

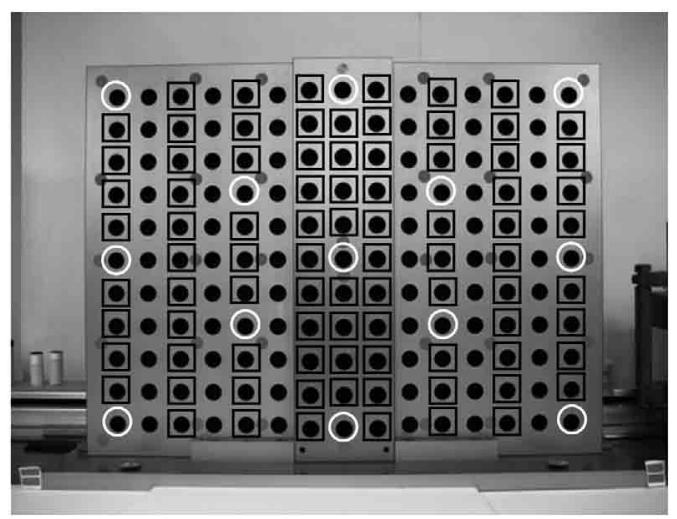

図 1 テストターゲット
対して使用するものである。また，本研究での結果は 5 回測定の平均值である。

\section{1 カメラキャリブレーション}

本研究でいうカメラキャリブレーションとは, 空間 後方交会法により外部標定要素 \{カメラの位置 $\left(X_{0}\right.$, $\left.Y_{0}, Z_{0}\right)$, 姿勢 $\left.(\omega, \varphi, x)\right\}$ および内部標定要素 $\{$ 主点位 置 $\left(u_{0}, v_{0}\right)$, 焦点距離 $(f)$, スケールファクタ $(a)$, せん 断係数 $(b)$, レンズ歪み係数 $\left.\left(K_{1}, K_{2}, K_{3}, P_{1}, P_{2}\right)\right\}$ を求 めることであり, 各基準点に対して誘導される下記の 共線条件式が観測方程式となる。

$$
\left.\begin{array}{l}
x=-f \frac{m_{11}\left(X-X_{0}\right)+m_{12}\left(Y-Y_{0}\right)+m_{13}\left(Z-Z_{0}\right)}{m_{31}\left(X-X_{0}\right)+m_{32}\left(Y-Y_{0}\right)+m_{33}\left(Z-Z_{0}\right)} \\
y=-f \frac{m_{21}\left(X-X_{0}\right)+m_{22}\left(Y-Y_{0}\right)+m_{23}\left(Z-Z_{0}\right)}{m_{31}\left(X-X_{0}\right)+m_{32}\left(Y-Y_{0}\right)+m_{33}\left(Z-Z_{0}\right)}
\end{array}\right\}
$$

ここに, $x, y$ : 画像座標, $X, Y, Z$ : 基準点の三次元 座標, $m_{11 \sim 33}$ : 回転量 $\omega, \varphi, x$ からなる回転要素

\section{2 スケールファクタ}

デジタル写真測量において観測される像点の座標 は，モニ夕上で観測される画素座標 $(u, v)$ であり，七 ンサ上の画像座標 $(x, y)$ を観測することは不可能で ある。そのため, 画素座標はスケールファクタおよび せん断係数を用いた次式により算出される (Faugeras \& Toscani, 1987)。

$u=u_{0}+a x+b y$

$v=v_{0}+c y$

ここに, $u, v$ : 画素座標, $x, y$ : 画像座標, $u_{0}, v_{0}$ : 主 点位置に対する画素座標

なお，スケールファクタとは(2)式において画素座標 から画像座標への変換係数 $a, c$ であり, 本研究ではデ ジタルカメラの仕様書に記載されているセンサタイプ から推定したセンササイズを $l_{x} \times l_{y}(\mathrm{~mm})$ とするとき (3)式より算出される值をスケールファクタとして採用 することとした。

$a=\frac{1}{p_{x}}=\frac{N_{c x}}{l_{x}}, c=\frac{1}{p_{y}}=\frac{N_{c y}}{l_{y}}$

ここに, $N_{c x}$ : 画面 1 行に対する画素数, $N_{c y}$ : 画面 1 列に対する画素数

\section{3 レンズディストーション}

レンズディストーションは, デジタル写真測量を行 
なう上で最も重要なパラメータの一つである。そのた め，これまでに多くのレンズディストーションモデル が提案されているが，本研究では Brown（1971）によ り提案され, 現在広く利用されている放射方向歪み ((5) 式）と接線方向歪み（(6)式）とを考慮した(4)式により レンズディストーションを検討することとした。なお, 放射方向歪みとは図 2 -(a)に示すように像がレンズ中 心から放射方向に縮むたる型，あるいは伸びる糸卷き 型があるが，一般に広角側でたる型の放射方向歪みが 表れ，望遠になるにつれて糸卷き型に変化する歪みで ある。また，接線方向歪みとは図 2 -(b)に示すように像 がレンズ中心からの放射線状において接線方向にずれ た位置に結像する歪みである。

$$
\begin{aligned}
& x=x^{\prime}+\frac{x^{\prime}}{r}\left(K_{1} r^{3}+K_{2} r^{5}+K_{3} r^{7}\right)+P_{1}\left(r^{2}+2 x^{\prime 2}\right)+2 P_{2} x^{\prime} y^{\prime} \\
& y=y^{\prime}+\frac{y^{\prime}}{r}\left(K_{1} r^{3}+K_{2} r^{5}+K_{3} r^{7}\right)+P_{2}\left(r^{2}+2 y^{\prime 2}\right)+2 P_{1} x^{\prime} y^{\prime} \\
& d(r)=K_{1} r^{3}+K_{2} r^{5}+K_{3} r^{7}
\end{aligned}
$$

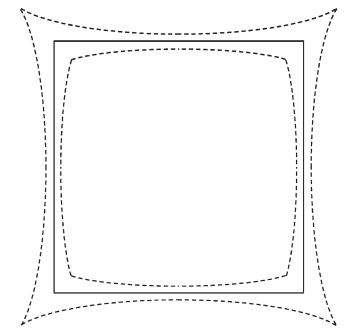

(a) 放射方向歪み

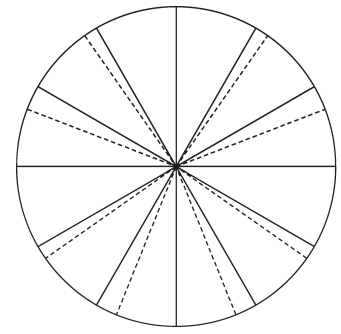

(b) 接線方向歪み
図 2 レンズディストーションイメージ

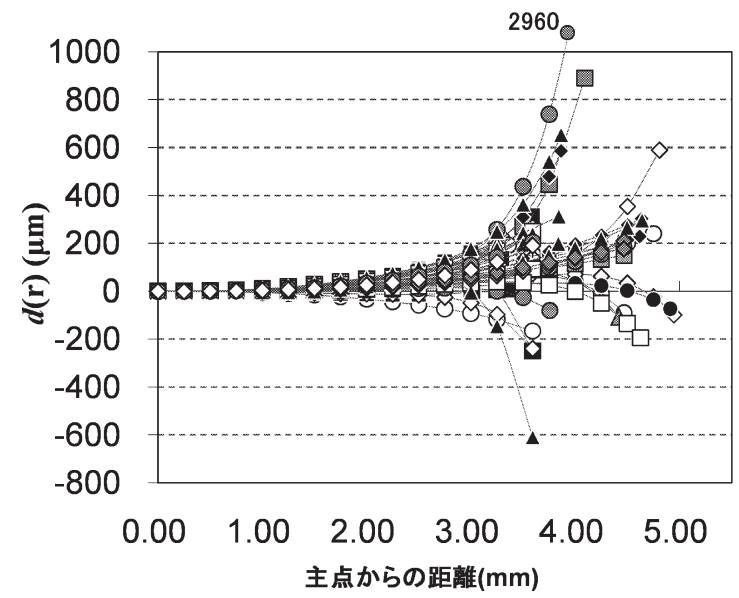

(a) 放射方向歪み
$P(r)=\left(P_{1}^{2}+P_{2}^{2}\right)^{1 / 2} r^{2}$

ここに, $r=\sqrt{x^{\prime 2}+y^{\prime 2}}, x, y:$ レンズ歪み補正後の画像 座標, $x^{\prime}, y^{\prime}$ : レンズ歪み補正前の画像座標, $K_{1}, K_{2}$, $K_{3}$ : 放射方向歪み係数, $P_{1}, P_{2}$ : 接線方向歪み係数

図 3 は, 各カメラの中央画像に対するカメラキャリ ブレーションより得られた内部標定要素の值を用いて (5)，(6)式より算出された放射方向歪みおよび接線方向 歪みである。図 3 より, 放射方向歪みの変動は非線形 であること，放射方向歪みの最大值は $2,960 \mu \mathrm{m}$, 最小 值は $2 \mu \mathrm{m}$, 接線方向歪みの最大值は $29 \mu \mathrm{m}$, 最小值は $1 \mu \mathrm{m}$ であり, 民生用デジタルカメラにおいても接線 方向歪みに比べて放射方向歪みの影響が非常に大きい ことが理解される。いっぽう，画角が大きくなればレ ンズ歪みも大きくなるものと推測されるが，放射方向 歪みにおいて大きな歪み量である $2,960 \mu \mathrm{m}, 890 \mu \mathrm{m}$, $654 \mu \mathrm{m}$ に対する画角はそれぞれ $71^{\circ} ， 56^{\circ} ， 75^{\circ}$ であり， また接線方向歪みにおいて $29 \mu \mathrm{m}, 16 \mu \mathrm{m}$ に対寸る画角 は共に $61^{\circ}$ であり本研究からは画角とレンズ歪みとの 関連性は確認されなかった。

\section{4. 精度検証}

本研究では各内部標定要素が計測精度に及ぼす影響 を安定性，検証点に対する計測精度の良否を信頼性お よび落下などの衝撃が計測精度に及ぼす影響を堅牢性 として民生用デジタルカメラの精度検証を行なうこと とする。

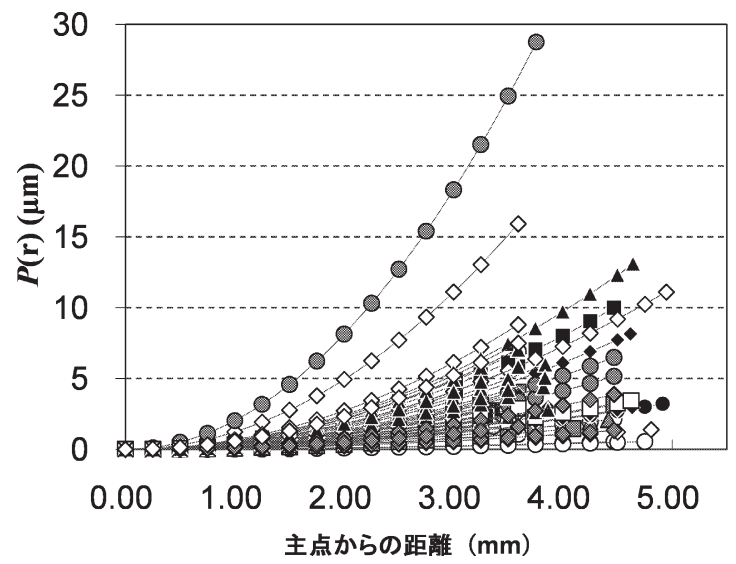

（b）接線方向歪み

図 3 レンズ歪み 


\section{1 安定 性}

ここでは内部標定要素を表 2 に示す項目ごとに分け て実施されるカメラキャリブレーションにより，民生 用デジタルカメラにおける内部標定要素の安定性につ いて検討を行なう。なお，表 2 における「固定」とは 項目ごとに記した内部標定要素を既知量として扱うこ とを意味している。例えば, Case 1 では画面中心の值 を既知量とし， Case 2 では Exifに記載された焦点距 離, Case 3 では Exif 情報が記録されるデジタルカメ ラの場合は正方画素が採用されることから(2)式におい て $a=c$ とし, せん断係数 $b$ は 0 として扱うことを意 味している。ただし, Case 4 以降における「固定」と はレンズディストーション係数を全て 0 とするもので ある。すなわち, Case 4 では放射方向歪み $\left(K_{1}, K_{2}, K_{3}\right)$ を考慮しないことであり, Case 5 以降も同様である。

図 4 は項目ごとの検討結果を示したものであるが, 相対精度とは項目ごとに検証点86点に対して算出され る平均二乗誤差の平方和を, 内部標定要素を全て未知

表 2 キャリブレーションモデル

\begin{tabular}{|l|lr|l|ll|}
\hline Case 1 & $u_{0}, v_{0}$ & 固定 & Case 6 & $K_{2}$ & 固定 \\
\hline Case 2 & $f$ & 固定 & Case 7 & $K_{3}$ & 固定 \\
\hline Case 3 & $a, b$ & 固定 & Case 8 & $P_{1}, P_{2}$ & 固定 \\
\hline Case 4 & $K_{1}, K_{2}, K_{3}$ & 固定 & Case 9 & $P_{1}$ & 固定 \\
\hline Case 5 & $K_{1}$ & 固定 & Case 10 & $P_{2}$ & 固定 \\
\hline
\end{tabular}

量とした際に算出される平均二乗誤差の平方和で除し た值 $\left(\sqrt{\sigma_{X}^{2}+\sigma_{Y}^{2}+\sigma_{Z}^{2}} / \sqrt{\sigma_{X 0}^{2}+\sigma_{Y 0}^{2}+\sigma_{Z 0}^{2}}\right)$ である。すなわ ち, この值が大きいほど精度は低下することを意味し ており, 計測精度はその内部標定要素の影響を受ける ということになる。

さて, 筆者らは民生用デジタルカメラをデジタル写 真測量に利用する場合には, 特に放射方向歪みの評価 が重要であることを示してきた（近津ら，2001；近津 ら， 2003 ; 高橋・近津，2008）。このことからも当然想 定されることであるが, Case $4\left(K_{1} \sim K_{3}\right.$; 固定) にお いて著しい精度低下を示していることから，民生用デ ジタルカメラにおいては特に放射方向歪みの影響が非 常に大きいことが改めて理解される。

以下, Case 1 ( $u_{0}, v_{0}$; 固定)でも明らかな精度低下 が確認される。また, Case 2 ( $f$; 固定) においても Case 1 と同様に精度低下が確認されるが, これは Exif に記載されている焦点距離と写真測量における画面距 離とは異なるものであり, 実際には一致しないことに 起因するものと推測される。Case $3(a, b$; 固定)では ほぼ全ての機種で精度低下は確認されないが, 一部の 機種では20倍以上の著しい精度低下を示した。この要 因としてはこれらの機種には一般的な正方形素子が採 用されていなかったことが原因であると判明された。 したがって, Case 3 による精度低下は見られないもの と判断される。

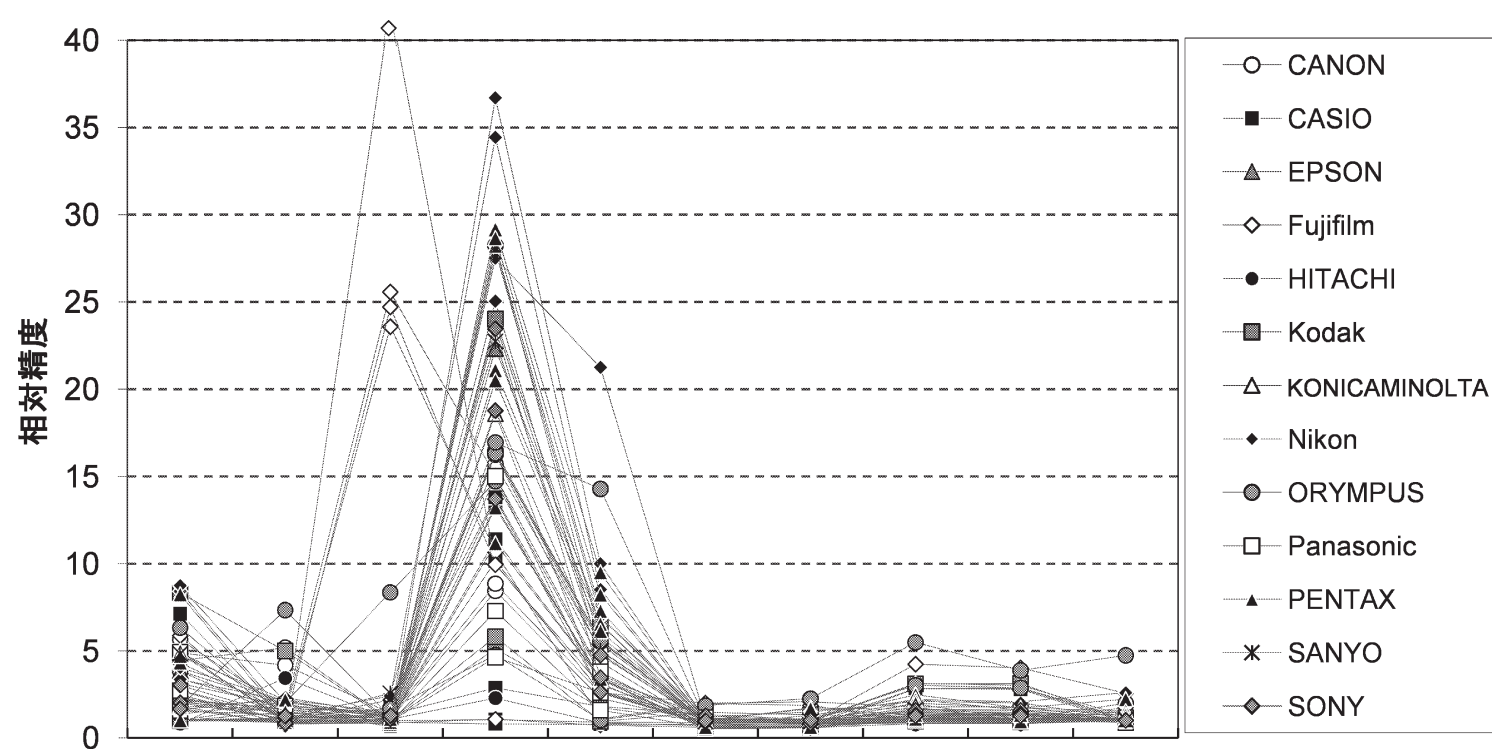

Case1 Case2 Case3 Case4 Case5 Case6 Case7 Case8 Case9 Case10 図 4 安定性の評価 
いっぽう, Case 5 ( $K_{1}$; 固定) は放射方向歪み係数 のうち $K_{1}$ のみを考慮しなかった場合であるが，この 場合には Case 4 に次いで精度低下の度合いが大きい こと抢よびCase 6 ( $K_{2}$; 固定), Case 7 ( $K_{3}$; 固定 $)$ の精度低下は小さいことを考慮すると放射方向歪みの 中でも $K_{1}$ が精度に与える影響が最も大きいこと, さ らに接線方向歪みの係数 $P_{1}, P_{2}($ Case $8 \sim 10)$ に関する 精度低下は小さいことが確認される。これは, デジ夕 ル写真測量やコンピュータビジョンの分野において, 放射方向歪みのうち $K_{2}, K_{3}$ が精度に与える影響は $K_{1}$ に比べて非常に小さいこと（Brown，1971；Karara＆ Abdel-Aziz, 1974 ; Tsai, 1986 ; Habib \& Morgan, 2003 ; Laebe \& Foerstner, 2004）抢よび高精度デジ タル写真測量以外は接線方向歪み $P_{1}, P_{2}$ の影響は無視 できること（Fraser, 1997 ; Doerstel et al., 2003) か らも, 本研究での結果の妥当性が理解される。

ところで, 主点位置は放射方向歪みに次いで精度に 与える影響が大きいことが理解されたため, ここに改 めて主点位置の変動を検討したものが図 5 である。な お，図 5 は画面中心とキャリブレーション後の主点位 置との差をそれぞれ画面中心の值で除して正規化した ものである。図 5 より機種やメーカーごとに変動は 様々であるが，主点位置のズレと精度低下を示した機 種との関連性は確認されなかった。したがって, 民生 用デジタルカメラの安定性を考慮した場合, 主点位置 $\left(u_{0}, v_{0}\right)$, 焦点距離 $(f)$, スケールファクタ $(a)$, せん断

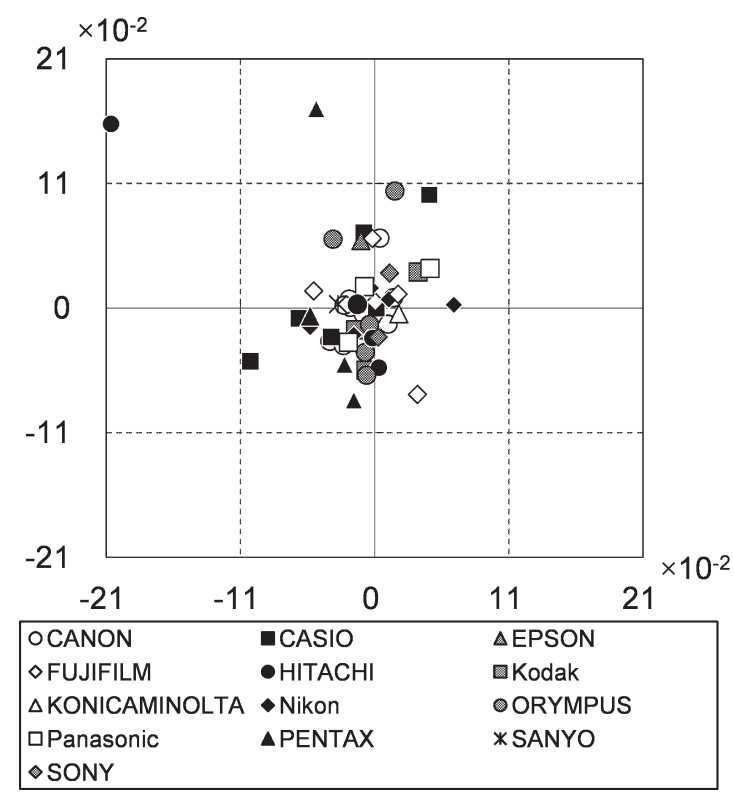

図 5 主点位置の変動
係数 $(b)$, 放射方向歪み係数 $\left(K_{1}\right)$ を考慮することが重 要であり, 特に最近の高解像度化から注目を集めてい るカメラ付き携帯電話をデジタル写真測量に用いる場 合には $K_{2}, K_{3}$ および $P_{1}, P_{2}$ を考慮することにより高 精度デジタル写真測量が可能になることも考慮すると (高橋・近津, 2009), 5 次, 7 次の放射方向歪み係数 $\left(K_{2}, K_{3}\right)$ 抢よび接線方向歪み係数 $\left(P_{1}, P_{2}\right)$ を考慮した 10 個の内部標定要素から構成されるキャリブレーショ ンモデルが機種の影響を受けず安定したキャリブレー ションモデルであると判断する。しかるに，本研究の 以降の部分においてはこの10パラメータキャリブレー ションモデルを採用する。

\section{2 信 頼 性}

ここでは, 計測精度により民生用デジタルカメラの 信頼性について検討を行なうものとし, 各カメラに対 する計測精度を示したものが図 6 である。なお，計測 精度とは近接デジタル写真測量において広く利用され ている一つの指標であり, 平均標準誤差 $\left(\sigma_{c}\right)$ および計 測対象の大きさ $(D)$ から次式より $\sigma_{c} / D$ として算出さ れる值である (Fraser, 1996)。

$\frac{\sigma_{c}}{D}=\frac{\sqrt{\left(\sigma_{X}^{2}+\sigma_{Y}^{2}+\sigma_{Z}^{2}\right) / 3}}{\sqrt{D X^{2}+D Y^{2}+D Z^{2}}}$

ここに, $\sigma_{c}$ : 平均標準誤差, $\sigma_{X, Y, Z}$ : 検証点 86 点に対す る $\mathrm{X}, \mathrm{Y}, \mathrm{Z}$ 座標の平均二乗䛊差

$D$ : 対象物の大きさ, $D X, D Y, D Z$ : 対象物の $\mathrm{X}, \mathrm{Y}, \mathrm{Z}$ 方向の大きさ

また, 図 6 中の曲線は(8)式において読み取り誤差を 1/10画素として算出される標準誤差 (Abdel-Aziz, 1982）を(7)式にあてはめて得られたものである。

$\sigma_{X 0}=\sigma_{Y 0}=\frac{H}{f} \sigma_{p}, \sigma_{Z 0}=\sqrt{2} \frac{H}{f} \frac{H}{B} \sigma_{p}$

ここに, $H$ : 撮影高度, $f:$ 焦点距離, $B$ : 基線長, $\sigma_{p}$ : 読み取り誤差 $(1 / 10$ 画素 $)$

図 6 より, 解像度の増加とともに計測精度が向上し ているが, 400万画素以上では計測精度に大きな違いが ないことが確認される。また, ほぼ全ての機種で標準 誤差と同程度以上の計測精度が得られていることが理 解されるが, 800 万画素の一部の機種においては標準䛊 差との間に差が確認される。しかし, ほとんどの機種 において $1 / 20,000$ 程度の計測精度が得られているこ とから, 読み取りは $1 / 10$ 画素以上(最大で $1 / 18$ 画素) の精度で行われていることが確認された。 


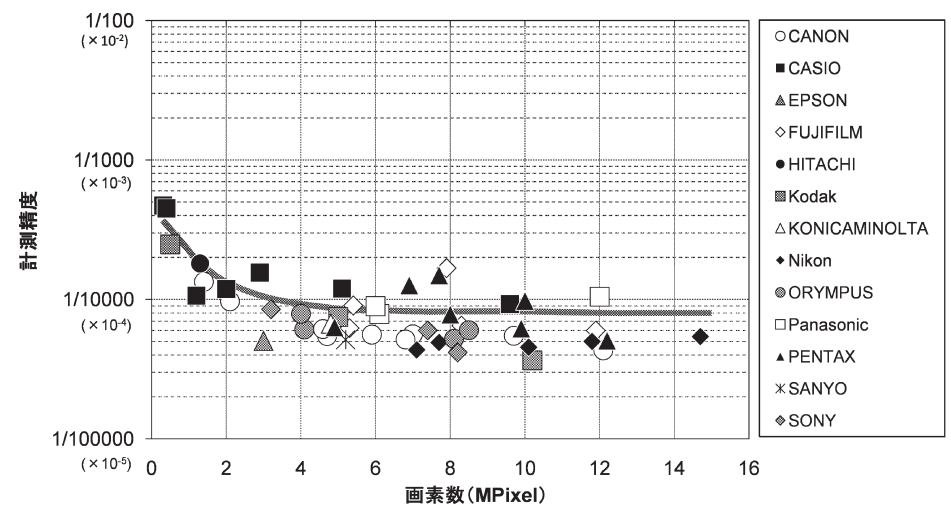

図 6 信頼性の評価

\section{3 堅 牢 性}

民生用デジタルカメラの軁体・内部構造の堅牢性の 要因には温度変化や経年変化の影響が考えられるが, 落下等の衝撃による光軸のズレなどの影響はデジタル 写真測量から見てデジタルカメラの堅牢性を考慮する 上で重要な要素の一つである。したがって，ここでは 民生用デジタルカメラの落下による影響が計測精度と 内部標定要素に与える影響について検討を行なうこと とする。なお，ここでの実験概要は民生用デジタルカ メラ (CANON, 10M) を90cmの高さから落下させ, 落下後に基線比 0.34 としてトリプレット撮影を 5 回ず つ行なうという操作を50回繰り返す。

図 7 は落下ごとに図 1 の白丸で印した基準点 13 点を 用いたカメラキャリブレーションを実施した後, 算出 された検証点に対する相対精度を示したものである。 なお，ここでの相対精度とは落下ごとに算出される検 証点に対する平均二乗誤差の平方和を落下前に算出さ れた検証点に対する平均二乗誤差の平方和で除した值

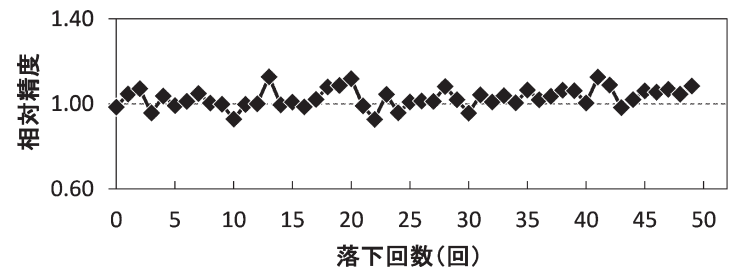

図 7 落下ごとの相対精度の変動

である。

また, 図 8 に示す変動比とは落下ごとのカメラキャ リブレーションにより算出される各内部標定要素を落 下前のカメラキャリブレーションにより算出された各 内部標定要素でそれぞれ除した值であり，ここでの結 果も5 回測定の平均值である。

図 7 より，まず気づくことは落下中における相対精 度に大きな違いは見られないことである。しかし, 図 8 より放射方向歪み係数 $\left(K_{2}, K_{3}\right)$ は落下直後から顕著 な変動を示していることが理解される。また, $K_{2}, K_{3} に$ 比べて変動率は小さいもののせん断係数 $(b)$ に関して

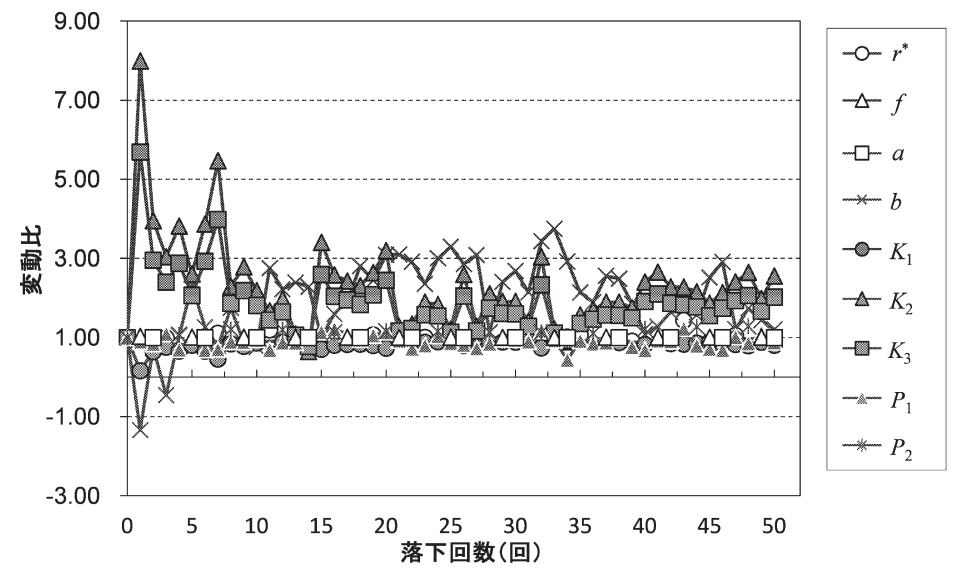

目 8 落下ごとの内部標定要素の变動 


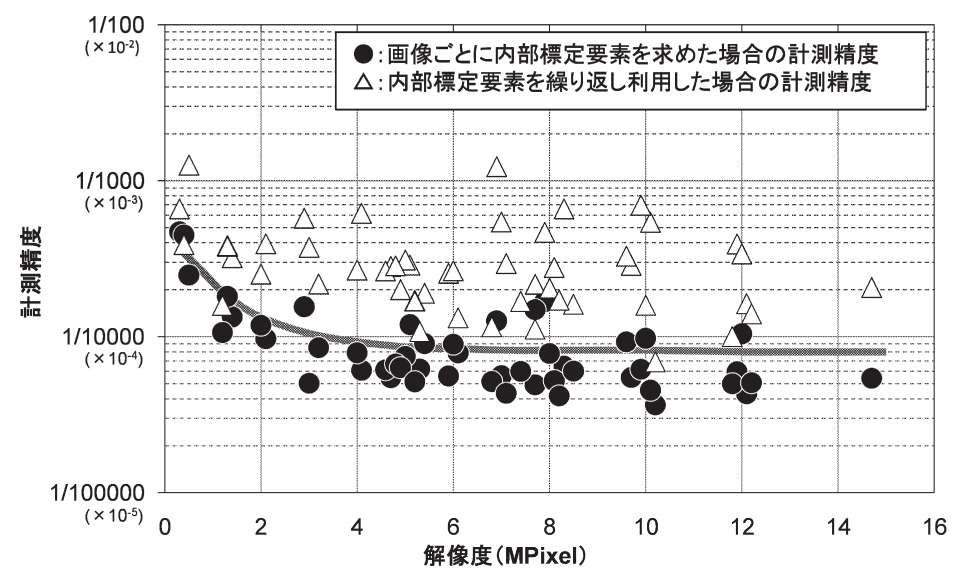

図 9 内部標定要素の繰り返し利用による計測精度の関係

も落下直後から変動が確認されるが, これら以外のパ ラメータに関してほとんど変動が認められない。した がって, 内部構造は落下の衝撃により何らかの影響を 受けているものと推測されるが，落下による影響はカ メラキャリブレーションにおける放射方向歪み係数 $\left(K_{2}, K_{3}\right)$ およびせん断係数 $(b)$ で相互に補っているも のと判断される。以上の結果からもせん断係数 $(b)$ お よび放射方向歪み係数 $\left(K_{2}, K_{3}\right)$ をも考慮した 10 パラ メータカメラキャリブレーションモデルの妥当性が理 解される。

\section{5. 内部標定要素の繰り返し利用}

近年民生用デジタルカメラの普及に伴い簡便的写真 測量の実施の観点から, 事前に求めておいた内部標定 要素の值を繰り返し利用する光景を度々目にするが, 写真測量におけるカメラキャリブレーションでは数学 モデルを満なす值として内部標定要素の各值が求めら れているにすぎないことを考慮すると, 予㛏㥁す いた内部標定要素を繰り返し利用してよいのかという 疑問が残る。

そこで, ここでは子女求めておいた内部標定要素を 繰り返し利用することの妥当性について検討を行なう こととする。すなわち, トリプレット画像のうちの中 央画像に対する 10 パラメータカメラキャリブレーショ ンにより得られた内部標定要素の值を左右のカメラに 共通な既知量として与え, 外部標定要素 \{カメラの位 置·姿勢\}のみを未知量としてカメラキャリブレーショ ンを行ない, その結果算出される検証点に対する平均 二乗䛊差で内部標定要素の繰り返し利用が計測精度に
与える影響を評価しようとするものである。

図 9 は計測ごとにカメラキャリブレーションを実施 して得られた計測精度と, 内部標定要素を繰り返し利 用して得られた計測精度との関係を示したものであ る。図 9 において○が計測ごとにカメラキャリブレー ションを実施して得られた計測精度であり， $\triangle$ が内部 標定要素を繰り返し利用して得られた計測精度を示し ているが，機種ごとにばらつきはあるものの，ほぼ全 ての機種において精度低下を示しており, 最大で12倍, 最小で1.5倍, 平均で 4 倍の精度低下が確認されたが機 種と精度低下との関連性は認められなかった。また， この結果はほとんど同時に撮影された中央画像での内 部標定要素の值を利用した結果であることを考慮する と, 実際のデジタル写真測量において内部標定要素を 繰り返し利用した場合には極めて精度の低いデジタル 写真測量が行われる危険性があることを十分に認識し ておく必要があると判断される。したがって，民生用 デジタルカメラによりデジタル写真測量を行なう場合 には画像ごとに10個の内部標定要素を考慮したカメラ キャリブレーションを実施することが重要であるとい える。

\section{6.まとめ}

本研究では30 1, 470万画素の民生用デジタルカメ ラ 13 社 50 機種を用いて民生用デジタルカメラの内部標 定要素が計測精度に及ぼす影響について改めて検証を 行ない民生用デジタルカメラによるデジタル写真測量 の実用性について検討を行なった。その主な結果を以 下に列挙する。 
- 内部標定要素において精度低下に一番影響を与える パラメー夕は放射方向歪みである。

・放射方向歪みの中で $K_{1}$ の影響が計測精度に及ぼす 影響が最も大きく， $K_{2}, K_{3}$ は $K_{1}$ に比べて影響度合 いが非常に小さい。

・画素構造の違いによるスケールファクタへの影響 や, 主点位置, 焦点距離および接線方向歪みが計測 精度に及ぼす影響は無視できない。

- 解像度の上昇とともに計測精度も上昇し, 標準誤差 と同程度以上の精度が得られているが400万画素以 上では計測精度において大きな変化が見られず，1/ 20,000 程度の計測精度が期待される。

・カメラの内部構造は落下の衝撃により明らかな影響 を受けているが，落下ごとの相対精度に大きな変化 は見られない。

- 堅牢性は主点位置, 焦点距離, せん断係数, 放射方 向歪み係数および接線方向歪み係数を未知量とした 数学モデルにより相互に補われているものと判断さ れる。

・カメラキャリブレーションは画素構造の違いや堅牢 性を考慮すると, 内部標定要素10個のキャリブレー ションモデルの利用が妥当であると判断された。

・内部標定要素を繰り返し利用した場合には, ほぼ全 ての機種で精度低下を示し最大で12倍，最小で1.5 倍, 平均で 4 倍の精度低下が確認された。

以上の結果から, 画像ごとに10個の内部標定要素を 考慮したカメラキャリブレーションを実施することに より，民生用デジタルカメラによる高精度デジタル写 真測量は十分に達成されるものと判断される。

(受付日2010.3.9, 受理日2010.7.9)

\section{参考文献}

高橋洋二，近津博文，2008. 民生用デジタルカメラの 内部標定要素と計測精度の関係に関する研究, 写真 測量とリモートセンシング，47(5), pp.71-76.

高橋洋二, 近津博文, 2009. 近接デジタル写真測量に おけるカメラ付き携帯電話の精度検証, 写真測量と リモートセンシング, 48(5), pp.299-307.

近津博文, 国井洋一, 中田隆司, 2001. デジタル写真

測量からみた 300 万画素デジタルスチルカメラの精

度検証, 写真測量とリモートセンシング, 40(2), pp. $33-38$.

近津博文, 他 3 名, 2003. 民生用デジタルスチルカメ
ラによるデジタル写真測量システム“3DiVision”の 構築, 写真測量とリモートセンシング, 42(3), pp. 6 $-16$.

Abdel-Aziz Y.I., 1982. Accuracy of the Normal Case of Close-Range Photogrammetry, Photogrammetric Engineering and Remote Sensing, 48(2), pp. 207-213.

Brown D.C., 1971. Close-Range Camera Calibration. Photogrammetric Engineering, 37(8), pp.855-866.

Doerstel .C., Jacobsen K., Stallmann D., 2003. DMC -Photogrammeric Accuracy-Calibration Aspects and Generation of Synthetic DMC Images, Optical 3-D Measurement Techniques VI, Vol. I, pp.74-82.

Faugeras O.D., Toscani G., 1987. Camera Calibration for 3D Computer Vision, Proc. of International Workshop on Industrial Application of Machine Vision and Machine Intelligence, IEEE TH0166-9, pp.240-247.

Fraser, C.S., 1997. Digital camera self-calibration. ISPRS Journal of Photogrammetry \& Remote Sensing, 52(4), pp.149-159.

Fraser C.S., Hanley H.B., 2004. Developments in Close-Range Photogrammetry for 3D Modelling The Iwitness Example, International Archives of Photogrammetry, Remote Sensing and Spatial Information Sciences, Vol. XXXVI-5/W1, ISSN pp.1682-1777.

Fraser C.S., 1996. Close Range Photogrammetry and Machine Vision, Whittles Publishing, pp.256-281. Habib A.F., Morgan M.F., 2003. Automatic calibration of low $^{-}$cost digital cameras, Optical Engineering, 42(4), pp.948-955.

Karara H.M., Abdel-Aziz Y.I., 1974. Accuracy Aspects of Non-Metric Imageries, Photogrammetric Engineering, 40(10), pp.1107-1330.

Laebe T., Foerstner W., 2004. Geometric Stability of Low-Cost Digital Consumer Cameras. The International Archives of the Photogrammetry, Remote Sensing and Spatial information Sciences, Vol. XXXV, B1, pp.528-534.

Tsai R.T., 1986. An Efficient and Accurate Camera Calibration Technique for 3D Machine Vision, Proceedings CVPR '86, pp.364-374. 